\title{
COMMERCIAL TRUSTS AS \\ BUSINESS ORGANIZATIONS: AN INVITATION TO COMPARATISTS
}

\author{
STEVEN L. SCHWARCZ*
}

\section{INTRODUCTION}

Traditionally restricted to gratuitous transactions, ${ }^{1}$ trusts are increasingly employed as business organizations in a wide range of commercial and financial transactions in the United States. ${ }^{2}$ They are commonly used, for example, in asset securitization transactions, ${ }^{3}$ have become a primary tool for investing pension moneys, ${ }^{4}$ and are the preferred form for structuring mutual funds. ${ }^{5}$ There is, however, relatively little scholarly or systematic understanding of these commercial uses of trusts ("commercial trusts"). ${ }^{6}$

Copyright (C) 2003 by Steven L. Schwarcz.

* Professor of Law, Duke University; Founding Director, Duke Global Capital Markets Center; Adj. Professor of Law, The Fuqua School of Business. E-mail: Schwarcz@law.duke.edu. I thank Deborah A. DeMott, Ralf Michaels, and Joanna Benjamin for invaluable comments and Matthew Mason and Emily A. Locher for helpful editorial and research assistance.

I dedicate this essay to the memory of my dear friend and colleague, Herbert L. Bernstein.

1. See, e.g., John H. Langbein, The Contractarian Basis of the Law of Trusts, 105 YALE L.J. 625, 632 (1996).

2. John H. Langbein, The Secret Life of the Trust: The Trust as an Instrument of Commerce, 107 YALE L.J. 165, 172 (1997) (noting that perhaps trillions of dollars of mortgage, credit card, automobile, and student loan debt is financed through trusts) (hereinafter Langbein, The Secret Life of the Trust).

3. For an introduction to asset securitization, see SteVEn L. SChwArCZ, STRUCTUREd Finance, A Guide to the Principles of Asset Securitization (3d ed. 2002); Steven L. Schwarcz, The Alchemy of Asset Securitization, 1 STAN. J.L. BUS. \& FIN. 133 (1994) (hereinafter Schwarcz, Alchemy).

4. "American pension trusts have attained stupendous size and importance ... [and, as of year-end 1996,] own more than a quarter of American equities and about half of all corporate debt." Langbein, The Secret Life of the Trust, supra note 2, at 168-69.

5. "As of May 1997, American mutual funds held nearly $\$ 4$ trillion in assets [and] about half or more of American mutual funds take the trust form." Id. at 171 (footnotes omitted). See also Jeffrey M. Laderman, Your Guide to Mutual Funds, BUS. WK., (Feb. 3, 1997), at 62: "In 1996 , some $\$ 223$ billion was handed over to equity-[mutual] fund managers .... It's almost as much as the gross domestic product of Sweden."

6. Steven L. Schwarcz, Commercial Trusts as Business Organizations: Unraveling the Mystery, 58 Bus. LAw. 559, 560 (2003) (hereinafter Schwarcz, Unraveling the Mystery). 
Outside the United States, parties similarly engage in securitization deals, invest in pension and mutual funds, and enter into other commercial and financial transactions that, in the United States, would use the trust form. ${ }^{7}$ The question thus arises: would commercial trusts also be useful in those non-U.S. transactions? The answer is complicated not only by the poor general understanding of commercial (as opposed to gratuitous) trusts but also by the fact that, in many non-U.S. jurisdictions other than the United Kingdom and other Commonwealth nations, trust law itself is relatively nascent. ${ }^{8}$

It is nonetheless important to at least begin to answer this question. The trust form is increasingly being scrutinized, and trusts or variations on the trust form are beginning to be embraced worldwide. Certain civil law and mixed-law jurisdictions, for example, already have adopted the trust form. ${ }^{9}$ Other civil law jurisdictions are starting to "adopt trust-like institutions," way to promote recognition by nontrust jurisdictions of trusts formed in other countries." One civil law scholar even claims that "the trust

7. See, e.g., Steven L. Schwarcz, The Universal Language of International Securitization, 12 DUKE J. COMP. \& INT'L L. 285 (2002) (discussing international securitization).

8. Michael Milo \& Jan Smits, Trusts in Mixed Legal Systems, in TruSTS IN MIXED LEGAL SYSTEMS 13 (J. M. Milo et al. eds., 2001) (observing that the type of divided-ownership characteristic of common law trusts does not exist in civil law countries). Cf. RESTATEMENT (THIRD) OF TRUSTS, Introductory Note to Chapter 1, at 3 (Tentative Draft No. 1, 1996) (noting that the trust is "peculiarly a product of the Anglo-American system"); Maurizio Lupoi, The Civil Law Trust, 32 VAND. J. TRANSNAT'L L. 967, 969 (1999) (observing that "there is a 'common core' at the basis of the Anglo-American trust").

9. Henry Hansmann \& Ugo Mattei, The Functions of Trust Law, 73 N.Y.U. L. REV. 434, 444 (1998) (citing mixed-law jurisdictions including Louisiana, Quebec, and Scotland, as well as civil-law jurisdictions including Japan, Lichtenstein, Israel, and several South American countries, that have adopted the trust).

10. Hansmann \& Mattei, The Functions of Trust Law, supra note 9, at 435-36 (citation omitted). These trust-like institutions include special guardianship institutions to manage assets on behalf of minors or incompetents, $i d$. at 442 (using examples from Italian law), as well as contractually-based civil-law relationships that have some of the attributes of a trust, $i d$. at 442-43. The latter relationships can be illustrated by the "romanistic fiduciary transaction," or fiducia, in which a party transfers ownership of specific assets to a manager, who then contractually manages these assets, as the transferor's agent, for the benefit of a third-party beneficiary designated by the transferor. $I d$. at 443 . The parties to these relationships, however, are not as fully protected as the parties to a common law trust. See id. at 443-44 (explaining that a buyer of these assets from the manager is "protected, even when he knows that the [m]anager is acting in bad faith"). Although the law of some civil-law countries has "evolved" to permit recovery of those assets, $i d$. at 443 , "the scope of this protection is generally not as broad as that afforded by the trust." Id. (comparing Italian and Swiss law, which allow limited recovery of the assets, with German law, which allows even less recovery). Hence, these trust-like relationships "do not provide completely adequate substitutes for the common law of trusts." Id. at 444.

11. Hansmann \& Mattei, The Functions of Trust Law, supra note 9, at 435-36 (citation omitted) (referring to the Hague Convention on the Law Applicable to Trusts and on their 
belongs to the civil law, whence it was imported in England during the formative period of the Chancellor's jurisdiction over trusts." ${ }^{12}$ In this scholar's view, the belief that trusts are inconsistent with civil law $^{13}$ reflects the failure of common and civil law scholars to seriously address the basis of trust law:

The mere fact that trusts exist in civil law countries should prove the point that there is no basic incompatibility with civil law structures. Why, then, is the opposite view held so unanimously? The simple answer is that common law scholars have not attempted a comparative study of the civil law institutions, while civil law scholars have not attempted a comparative study of trusts. ${ }^{14}$

Some civil law countries also have been moving legislatively to clarify that trusts are consistent with their law. It has been reported, for example, that "every European country has enacted legislation" shielding trust property from claims against mutual-fund and investment-firm intermediaries that operate as portfolio managers. ${ }^{15}$ Japan and Korea have adopted similar laws. ${ }^{16}$

Recognition, concluded July 1, 1985 (Hague Conference on Private International Law, available at http://www.hcch.net/e/conventions/text30e.html), providing conflicts of law rules by which non-trust countries can recognize foreign trusts). As of June 6, 2000, that Convention has been ratified by Australia, Canada, China (only with respect to its Hong Kong Special Autonomous Region), Cyprus, France, Italy, Luxembourg, Malta, Netherlands, United Kingdom, and the United States. See http://www.hcch.net/e/status/stat30e.html (visited Nov. 5, 2002).

12. Lupoi, The Civil Law Trust, supra note 8, at 968-69 (arguing for the existence of civil law trusts).

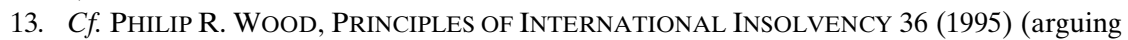
that traditional civil law objections to the trust may be based on a concern that trusts are unfair to creditors of the legal owner, who believe they can claim against all assets that the legal owner appears to own).

14. Lupoi, The Civil Law Trust, supra note 8, at 976.

15. Hansmann \& Mattei, The Functions of Trust Law, supra note 9, at 458-459 (citing examples from French, Italian, and German law, and also referencing applicable European Union directives). See also D.J. Hayton, S.C.J.J. Kortmann \& H.L.E. Verhagen, PRInCiPles of EUROPEAN TRUST LAW (1999) (examining ways of incorporating the common law trust into European law). But cf. e-mail from Dr. Joanna Benjamin, Reader in Law, London School of Economics and member of the Bank of England's Financial Markets Law Committee, to the author (Oct. 9, 2002) (observing that a "major challenge in achieving a single financial market in Europe is the lack of a domestic law of trusts in the civil jurisdictions making up all of Europe other than England and Ireland").

16. For Japan, see Shintaku Ho [Trust Law], Law No. 62 of 1922, art. 16, no. 1, translated in Eibun-Horei-Sha, EHS Law Bulletin Series Japan Vol. 6, CD1 (1994); See also KAZUO SHinOMIYA, Shintaku Ho 183 (Yuhikaku 1989); Mitsubishi SHINTAKU Ginko SHINTAKU GENKYUKAI, SHINTAKU NO HoMU TO JiTSUMU 51 (Kinyuzaiseijijyo Genkyukai, 3d ed. 1999). For Korea, see Sintakbop, Act No. 900 (1961), art. 22, translated in KorEA LEGISLATION RESEARCH InSTITUTE, STATUTES OF THE REPUbLiC OF KoREA Vol. 3, 361 (1997). 
Traditionally, however, comparative literature on trust law appears to have focused almost exclusively on gratuitous trusts. ${ }^{17}$ This is not surprising; the gratuitous trust is the historical prototype, and even the use of trusts for commercial purposes in the United States is fairly recent. ${ }^{18}$ Nevertheless, given their increasing dominance, the existence of commercial trusts should be taken into account for a fuller, and thus more accurate, picture.

This essay is a preliminary step in examining whether commercial trusts might be useful in non-U.S. transactions. ${ }^{19}$ It proceeds by redacting to fundamental principles, shorn of any uniquely U.S.specific considerations, - and thereby making accessible to foreign lawyers as well as comparative-law scholars - the analytical framework for commercial trusts that I constructed in a separate article. ${ }^{20}$ That framework differentiates commercial from gratuitous trusts, and also addresses such basic questions as whether commercial trusts are a better form of business organization than corporations and whether existing trust law is adequate to govern commercial trusts. ${ }^{21}$ The framework shows that commercial trusts and corporations can be thought of, in the United States, as mirror-image entities that respond to different investor needs; and that the essential distinction between these entities turns on the degree to which assets need to be placed at risk in order to satisfy the expectations of residual claimants. ${ }^{22}$

17. The only comparative literature on trust law I have found that addresses commercial trusts, albeit briefly, are Hansmann \& Mattei, The Functions of Trust Law, supra note 9, at 46669 \& 472-78; David Hayton, Hugh Pigott \& Joanna Benjamin, The Use of Trusts in International Financial Transactions, 17 J. INT'L BANKING \& FIN. L. 23 (2002).

18. Langbein, The Secret Life of the Trust, supra note 2, at 188.

19. That this essay is able to be even a preliminary step is thanks to the strong foundation of scholarship set by Professor John Langbein on trust law generally and by Professors Henry Hansmann and Ugo Mattei on comparative-trust law. Their works are cited throughout the essay, and I am doubly fortunate to have received their invaluable comments on the recent article, Unraveling the Mystery, supra note 6, from which this essay derives. None of these scholars, however, has answered such fundamental questions as what makes commercial trusts different from corporations. See, e.g., Hansmann \& Mattei, The Functions of Trust Law, supra note 9, at 479: "We are left ... with the question whether the differences between these two forms [corporations and trusts] are in any way fundamental ...." Although Prof. Langbein argues that trusts are more attractive because they facilitate pass-through taxation (The Secret Life of the Trust, supra note 2, at 189), that explanation does not fully explain the continued vitality of the commercial trust after tax law changes, made subsequent to his article, which allow most nonpublicly traded corporate entities in the United States to avoid entity-level taxes. See infra note 39 and accompanying text.

20. See Schwarcz, Unraveling the Mystery, supra note 6.

21. Id.

22. I refer to residual and senior claims and claimants in the economic sense. Senior claimants have the right to repayment of their claims prior to repayment of residual claims. Residual 
This essay does not, however, purport to provide a truly comparative analysis of commercial trusts. Such an analysis would need to be as much functional as legal. One might begin, for example, by identifying all the types of transactions in which commercial trusts are used in the United States, and then compare the characteristics of those commercial trusts with the characteristics of their counterpart business organizations in analogous transactions in other legal systems. That analysis is beyond the essay's scope.

\section{ANALYSIS}

A trust is "a fiduciary relationship with respect to property, arising as a result of a manifestation of an intention to create that relationship and subjecting the person who holds title to the property [the trustee] to duties to deal with it for the benefit of" third-party beneficiaries. ${ }^{23}$ This relationship therefore, as for a corporation, separates ownership (by the residual beneficiaries) from management (by the trustee) and imposes fiduciary duties on management to act for the benefit of the beneficiaries. ${ }^{24}$ Also, as for a corporation, the trust relationship provides for limited liability: beneficiaries of the trust may claim (absent breach of trust) only against the trust assets, not against personal assets of the trustee, ${ }^{25}$ nor may the trustee's personal creditors claim against the trust assets. ${ }^{26}$

claimants, however, have the right, traditionally associated with ownership, to all remaining value once the senior claims have been paid in full. See, e.g., Steven L. Schwarcz, Rethinking a Corporation's Obligations to Creditors, 17 CARDOZO L. REV. 647, 667 (1996).

23. Restatement (THIRD) of TRusts $\S 2$ (Tentative Draft No. 1, 1996) (although the Restatement itself does not specifically address commercial trusts; see id. $\S 1$, comment b, and $\S$ 5 , comment 1).

24. Although one explanation of the trust relationship is that the beneficiaries hold equitable title whereas the trustee holds mere legal title (historically, the distinction between legal and equitable interests being traceable to the separation of judicial functions in English courts of common law and chancery, RESTATEMENT (THIRD) OF TRUSTS $\S 2$ (Tentative Draft No. 1, 1996), Introductory Note at 3, this distinction "has not been one of universal acceptance." Id., Reporter's Notes on $\S 2$ (stating, for example, that "although the provisions of the Japanese Trust Law as a whole closely parallel trust law principles set out in the Restatement, Second, of Trusts, trust concepts in that country are based on and discussed in terms of obligation rather than legal and equitable property rights"). See also Shintaku Ho [Trust Law], Law No. 62 of 1922, art. 1.

25. RESTATEMENT (SECOND) OF TRUSTS $§ 204$ (1959) (non-liability of trustee for loss in absence of breach of trust).

26. Id., $\$ 266$ (person to whom trustee has become liable cannot reach trust property). Accord, Convention on the Law Applicable to Trusts and on their Recognition, supra note 23, art. 2(a) (providing that a trust's "assets constitute a separate fund and are not a part of the trustee's own estate"). 
Commercial trusts bear even greater resemblances to corporations. ${ }^{27}$ Unlike a gratuitous trust, in which the party transferring assets to the trust (the "settlor") receives no compensation for the conveyance, ${ }^{28}$ the settlor in a commercial trust-typically a corporation or financial institution-always receives payment for the assets conveyed to the trust. ${ }^{29}$ The settlor in a commercial trust also will retain a residual interest, entitling the settlor to retain any trust assets remaining once the business transaction is concluded. ${ }^{30}$ (In contrast, a settlor in a gratuitous trust may or may not retain a residual interest.) Commercial trusts are therefore bargained-for exchanges where resort to the trust form serves a commercial advantage.

This can be illustrated by a typical example from structured finance. A company settles a trust by transferring financial assets to the trust in return for payment in the form of trust certificates and a bargained-for residual interest in the trust. ${ }^{31}$ The company then raises funds by selling the trust certificates to capital-market investors, ${ }^{32}$ who buy the certificates expecting that the trust assets will generate sufficient cash to repay their investment plus the contractual rate of return specified in the certificates. ${ }^{33}$ The residual interest entitles the company to any assets remaining in the trust once the certificates are paid in full. ${ }^{34}$

27. Accord, Hansmann \& Mattei, The Functions of Trust Law, supra note 9, at 472 (noting that commercial trusts "bear[] an obvious resemblance to the corporation"). Trusts, in fact, were commonly used as a form of business enterprise in the 19th century. Langbein, The Secret Life of the Trust, supra note 2, at 188-89.

28. Langbein, The Contractarian Basis of the Law of Trusts, supra note 1, at 632.

29. Schwarcz, Unraveling the Mystery, supra note 6, at 562.

30. Id.

31. A trust certificate is simply a writing that evidences the holder's undivided interest, to the extent specified in the writing, in the trust assets. See Thomas S. Harman, Emerging Alternatives to Mutual Funds: Unit Investment Trusts and Other Fixed Portfolio Investment Vehicles, 1987 DUKE L.J. 1045, 1053.

32. Capital-market investors are investors in "markets where capital funds-debt and equity-are traded. Included [in these markets] are private placement sources of debt and equity as well as organized markets and exchanges." JOHN DOWNES \& JORDAN GOODMAN, DICTIONARY OF FINANCE AND INVESTMENT TERMS 59 (3d ed. 1991) (definition of capital markets).

33. Although in some trusts the senior trust certificates or debt instruments are issued directly to investors (with the proceeds and a residual trust certificate being paid to the settlor to purchase the financial assets), that difference would not affect this essay's analysis.

34. This residual amount can be significant. To ensure repayment, capital market investors usually demand that the amount of assets conveyed to the trust be well in excess of the minimum necessary to repay such investors. Schwarcz, Alchemy, supra note 3, at 141 . The residual claim to these assets after the investors are repaid therefore is a valuable property right which the settlor is unwilling to give up. Id. 
Thus, the deal is an arm's-length, negotiated bargain in which all parties benefit and the company does not give up more value than needed to make the deal work. The investors, as senior claimants of the trust, get their money back with interest. ${ }^{35}$ The company, as residual claimant, receives payment for the financial assets sold to the trust and is entitled to any residual value of those assets once the investors are paid in full. ${ }^{36}$ In economic terms, the deal is strikingly similar to a secured loan in which surplus collateral is returned to the debtor once lenders receive principal and interest.

To construct a more complete framework for analysis, I examined representative types of commercial trusts at length, ${ }^{37}$ which revealed that, at least descriptively, commercial trusts tend to be static entities that diversify risk and often avoid an entity-level tax. ${ }^{38}$ These features, however, are insufficient by themselves to create an analytical framework because they are not necessarily unique to commercial trusts; nothing prevents corporations, for example, from restricting their charters to become static entities, and corporations can certainly diversify risk by issuing different classes of shares. Moreover, most non-publicly traded entities with the functional attributes of corporations can, at least in the United States, now avoid entity-level taxes. ${ }^{39}$

I therefore added to the framework by examining commercial trusts from the three fundamental perspectives by which one can think about a business entity: for what purposes does the entity exist (its "legal existence"); how is the entity governed (its "governance"); and what effect does the entity have on its surroundings and vice versa (its "exogenous effects").

\section{LEGAL EXISTENCE}

Not all commercial trusts are recognized as having separate legal existence, ${ }^{40}$ and indeed some are recognized under certain laws but

35. Schwarcz, Unraveling the Mystery, supra note 6, at 563.

36. Id.

37. See id. at 563-73 (examining trusts used as special purpose vehicles, or SPVs, in structured finance transactions, trusts used to diversify lending risk, master trusts used to enable an originator of financial assets generally to sell interests therein to the broadest investor base, trusts used in mutual funds for pooling investor money in order to invest in securities, and deeds of trust used as the functional equivalent of a security device for the granting of collateral).

38. Id. at 573. For a discussion of entity-level taxes in cross-border transactions, see Schwarcz, The Universal Language of International Securitization, supra note 7, at 303-05.

39. Schwarcz, Unraveling the Mystery, supra note 6, at 565.

40. Cf. e-mail from Dr. Joanna Benjamin, supra note 15, at 1 (stating that, to her knowledge "under English law, trusts are never treated as legal persons"). 
not others. ${ }^{41}$ In contrast, corporations almost always are recognized as having separate existence at law. ${ }^{42}$ Business planners therefore may favor trusts where non-entity status is needed to avoid a tax. However, a trust's lack of legal existence could be troublesome if its beneficiaries are concerned that the company transferring assets to the trust might go bankrupt. ${ }^{43}$ If bankruptcy law did not recognize the trust, the assets thought to be conveyed to the trust would still belong to the bankrupt company. Therefore, where bankruptcy is a realistic risk, a commercial trust either is sought to be created under specific laws that recognize its existence, or else corporations are used. ${ }^{44}$

\section{GOVERNANCE}

From the standpoint of this second perspective, commercial trusts are seen to be static entities with passive managers (the trustees of the trust). ${ }^{45}$ This contrasts sharply with business corporations, whose managers tend to be aggressive and opportunistic to take advantage of business opportunities. I believe this reflects the most fundamental distinction between trusts and corporations.

To understand this distinction, note that in a corporation the residual claims, which are evidenced by shares of stock, are sold to third-party investors ("shareholders"). The shareholders expect a rate of return that compensates them for the money they voluntarily put at risk. If that rate of return is not forthcoming, they will not invest and the system of shareholder corporate finance would collapse. It therefore is essential that corporations engage in business ventures that are likely to increase their profitability. In contrast, a corporation's senior claimants (its creditors) will be paid principal and interest (the latter being their contractual rate of return) so long as the corporation is solvent. However, allowing a solvent corporation to engage in business ventures to increase its profitability brings no benefit to creditors, whereas failure of the venture might bring a risk of insolvency and hence loss.

The fundamental goals of a corporation's shareholders (residual claimants) and creditors (senior claimants) therefore compete. Corporate law resolves these competing goals by allowing managers-the

41. Schwarcz, Unraveling the Mystery, supra note 6, at 574.

42. See id.

43. In many non-U.S. jurisdictions, bankruptcy law is referred to as insolvency law. My analysis above would apply to companies subject to these laws, whatever they are called.

44. Id.

45. Id. at 575 . 
corporation's board of directors - to take risks in order to maximize corporate profitability (and thus shareholder return) so long as the corporation is not insolvent. ${ }^{46}$ For this reason, the board of directors is responsible, absent insolvency, to shareholders but not creditors. ${ }^{47}$

Trust law, on the other hand, developed historically from gratuitous trusts. The degree of conflict between senior and residual claimants that was seen with corporations is unlikely to arise in a gratuitous trust because the expectations of its claimants, in practice, tend to be consistent: to preserve the value of the trust assets. ${ }^{48}$ For example, a trust with no residual claimants avoids conflict by having only senior claims. A trust where the settlor is the only residual claimant-as in settlor transferring a life-estate in assets for the benefit of third party, residual to settlor-rarely creates a significant conflict because the settlor, unlike a corporate shareholder, normally would not expect a risk-weighted return on its claim. ${ }^{49}$ Even a trust where the residual claimants are third parties - as in husband transferring a life-estate in assets for the benefit of his wife, residual to his children-does not

46. Id. at 576 .

47. Id. Although "[n]ormally, we speak of directors owing a duty to the corporation[,] . . courts typically expand the statement of the directors' duty to say that directors owe their duty to the corporation and its shareholders. ... Normally, however, courts have refused to recognize that directors have fiduciary obligations to the corporation's creditors (or to other constituent groups beyond the shareholders)." FrAnKLIN A. GEVURTZ, CORPORATION LAW $\S 4.1 .5$, at 304-06 (2000) (citations omitted).

48. See, e.g., IIA Austin W. Scott \& William F. Fratcher, The Law of Trusts, $\$ 176$, at 482 (4th ed. 1987): "It is the duty of the trustee to use care and skill to preserve the trust property." Accord, id., $\S 174$, at 468 ("In making investments the trustee is under a duty not only to exercise such care and skill as a man of ordinary prudence would exercise in dealing with his own property, but he must use the caution of one who has primarily in view the preservation of the estate entrusted to him, a caution that may be greater than that of a prudent man who is dealing with his own property."); id. § 181, at 544-45 (even where a trustee is "authorized to make... land productive by managing it, he is not under a duty to lease it"); RESTATEMENT (THIRD) OF TRUSTS (Prudent Investor Rule) § 227, at 20 ("Normally, in investing the funds of a trust, the trustee's strategy must make preservation of the trust estate (including its purchasing power) a significant consideration"); GEORGE T. BOGERT, TRUSTS § 106, at 387 (6th ed. 1987) ("[A trustee] has no duty to make investments for the purpose of increasing the [real] value of the trust assets. He is not permitted to speculate with the trust principal"); David Hayton, English Fiduciary Standards and Trust Law, 32 VAND. J. TRANSNAT'L. L. 555, 556 (1997) (discussing the trustee's duty under English law to avoid investments that are "attended by hazard") (quoting Lord Watson).

49. I am not claiming there is no conflict. The distinction turns on the degree of conflict. $C f$. e-mail from John H. Langbein, Sterling Professor of Law \& Legal History, to the author (Aug. 10,2002 ) (observing that there is "an imbedded conflict of interest in every trust that has multiple interests, especially the common successive (life and remainder) estates"); Edward C. Halbach, Jr., Significant Trends in the Trust Law of the United States, 32 VAND. J. TRANSNAT'L. L. 531, 550 (1999) (discussing techniques for "avoiding conflicts between productivity requirements and optimal total-return investment objectives through creative trust design"). 
create the degree of conflict that occurs between a corporation's creditors and shareholders: the children, receiving a gift for which they gave nothing in return, could not reasonably expect the trustee to jeopardize the wife's life-estate solely in order to maximize the children's residual return. Although the children will want the trustee to ensure that the trust assets preserve their value, ${ }^{50}$ that goal does not allow the trustee to "endanger the safety of principal to produce a large income." ${ }^{51}$ Instead, trust law imposes a duty of impartiality: where "there are two or more beneficiaries of a trust, the trustee is under a duty to deal impartially with them. $"{ }^{52}$

As a practical matter, commercial trusts likewise avoid conflicts between senior and residual claimants. Although the settlor's interest, as residual claimant, is theoretically the inverse of the beneficiary's interest, as senior claimant (because each dollar used to pay the senior claimant reduces by a dollar the amount available to return to the residual claimant), this conflict is rarely problematic. The settlorresidual claimant, unlike a corporate shareholder, does not ordinarily expect a risk-weighted return on its claim. Instead, its business goal is simply to retain any surplus value in the trust's assets. ${ }^{53}$ So long as

50. And, indeed, trust law imposes on the trustee a "duty to ... the remainder beneficiaries [i.e., the residual claimant] to exercise reasonable care in an effort to preserve the trust property, and this duty ordinarily includes a goal of protecting the property's purchasing power." RESTATEMENT (THIRD) OF TRUSTS (Prudent Investor Rule) § 232.

51. Id. at 181-82. Accord, SCOTT \& FRATCHER, THE LAW OF TRUSTS, supra note 48, § 227 , at 18 (observing that while trust law today recognizes that "[a]ll investments . . . and all investment strategies involve some risk in the comprehensive sense of possible loss of real, inflationadjusted value, the duty of caution still calls for the prudent management of risk"). The duty of caution is reflected in "[c] ase law and prior Restatements [of the Law of Trusts which] have condemned 'speculation' and excessive risk ...." RESTATEMENT (THIRD) OF TRUSTS (Prudent Investor Rule) at 6 . Although a proposed Uniform Prudent Investor Act would, where enacted, substitute a requirement of sensitivity to risk in place of the directive to avoid speculation, that change is not expected to materially change "the outer reaches of the risk/return distribution." John H. Langbein, The Uniform Prudent Investor Act and the Future of Trust Investing, 81 IowA L. REV. 641, 650 (1996).

52. Restatement (THIRD), OF TRUSTS $\S 183$, at 149 (Duty to Deal Impartially with Beneficiaries). To understand how the duty of impartiality works, assume that the foregoing trust has $\$ 500,000$ of assets-a life-estate with which the wife is satisfied-and the opportunity to invest in a business transaction with a $90 \%$ chance of successfully doubling the assets but a $10 \%$ chance of losing all the assets. A trustee considering this investment would have to weigh the $10 \%$ chance that the wife will lose her entire life-estate against the $90 \%$ chance that the children's residual estate will be significantly increased. Even though the investment has a significantly positive expected value, it may well constitute excessive risk. If so, the trustee's duty of impartiality would prevent it from making the investment. Accord, Hayton, English Fiduciary Standards and Trust Law, supra note 48, at 556-64 (discussing the trustee's duty under English law).

53. Schwarcz, Unraveling the Mystery, supra note 6, at 578. 
there are no third-party residual investors, commercial trusts do not have the economic constraints that corporations have to be profitable. $^{54}$

The degree to which assets need to be placed at risk in order to satisfy the expectations of residual claimants therefore provides a key to distinguishing commercial trusts from corporations. Although the interests of a trust's senior and residual claimants are theoretically inconsistent, the expectations of all such claimants would be satisfied merely by preserving the value of the trust assets. Because preserving this value is usually a ministerial job, trustees can operate under a duty of impartiality. ${ }^{55}$

The expectations of senior and residual claimants of a corporation, however, are significantly more divergent: shareholders demand increased profitability, not merely preservation of corporate value, whereas creditors are concerned that risks taken to achieve profitability might lead to corporate insolvency. ${ }^{56}$ This divergence would make a corporate duty of impartiality difficult to apply. ${ }^{57}$ In place of that duty, corporate law requires, absent insolvency, that the duty of managers is to the residual claimants, i.e., the shareholders. This suggests that the trust form is useful where residual claimants of a business organization do not expect management to favor their class of claims over senior claimants. $^{58}$

54. If all the beneficiaries of a trust want it to be profitable, as in a mutual fund, there is not even a theoretical conflict; the trustee's obligation to achieve profitability then reflects the duty "to administer the trust solely in the interest of the beneficiary." RESTATEMENT (SECOND) OF TRUSTS, supra note 22, § 170(1) (duty of loyalty).

55. Schwarcz, Unraveling the Mystery, supra note 6, at 578.

56. The divergence of senior- and residual-claimant expectations also explains why corporate managers are generally better trained and more sophisticated than trustees.

57. See, e.g., Schwarcz, Rethinking a Corporation's Obligations to Creditors, supra note 22, at 672-77 (explaining the difficulties of trying to determine how directors of an insolvent corporation can balance their duties to shareholders and creditors). See also id. at 676 (likening such balancing to "the dilemma of comparing apples and oranges") and at 673 (observing that "[c]urrent law ... does not provide any hard and fast rules" on how to achieve the balance).

58. Accord, Hansmann \& Mattei, The Functions of Trust Law, supra note 9, at 473 (arguing that trust law helps to balance conflicting interests among a trust's claimants by "[m]aking the [trustee] a pure fiduciary, not subject to control by any of the" residual claimants). The foregoing analysis also helps to explain why the governance rules of corporation and trust law begin to converge in insolvency. See Schwarcz, Rethinking a Corporation's Obligations to Creditors, supra note 22, at 667-68 (discussing such convergence). The value of a residual claimant's claim against the business entity then approaches zero while the senior claimants face a risk of nonpayment; and indeed senior claimants will become de facto residual claimants to the extent of insolvency. Senior claimants therefore should be owed a fiduciary duty by the entity's managers. And, indeed, directors of an insolvent corporation have been held to owe a fiduciary duty to the corporation's creditors (senior claimants) as well as shareholders (residual claimants). Id. at 665- 


\section{EXOGENOUS EFFECTS}

This final perspective, exogenous effects, views the effect an entity has on its surroundings, and vice versa. In business, perhaps the most common exogenous effect is the cost of taxes. Taxes are generally imposed on the income of each entity that is recognized under tax law as having separate existence. Thus, absent an exemption from taxes, corporations generally would be subject to "entity-level" taxes. $^{59}$

Trusts also can affect third parties, such as by diversifying their risk. However, because corporations likewise can diversify risk, such as by issuing different classes of shares, ${ }^{60}$ this exogenous factor is neutral. Similarly, because investors in a trust (at least in the United States) are not usually liable for the debts and other obligations of the trust, ${ }^{61}$ an immunity that is generally the same as that of shareholders of a corporation, that exogenous factor is also neutral.

\section{FRAMEWORK FOR ANALYSIS}

The foregoing examination suggests the following framework for analysis:

Commercial trusts might not be recognized as having separate legal existence. This can allow a trust to avoid en-

68 and 668 n.100. Some have even referred to this shifting of corporate fiduciary duty as the "trust fund doctrine." Laura Linn, Shift of Fiduciary Duty Upon Corporate Insolvency: Proper Scope of Directors' Duty to Creditors, 46 VAND. L. REV. 1485, 1511-12 n.87 (1993) ("[t]he courts have reasoned that, upon insolvency, the directors become "trustees" for the creditors and hold corporate assets as a "trust fund" for the benefit of these investors).

59. In the United States, however, as a result of recent tax law changes, non-publicly traded entities with the functional attributes of corporations now can usually avoid entity-level taxes. Schwartz, Unraveling the Mystery, supra note 6, at 565 n.40.

60. See sentence prior to text accompanying note 39 supra.

61. James M. Ginocchi \& Kimberly A. Taylor, How "Limited" is Pennsylvania's Limited Liability Company Act?, 33 DuQ. L. ReV. 613, 649 (1995). See also IIIA Austin W. SCOTT \& William F. FRATCHER, THE LAW OF TRUSTS, \$274.1, at 521 (4th ed. 1998) (observing that "[b]y the weight of authoriy it is held that the beneficiaries are not personally liable ... where the beneficiaries [lack] power to control the conduct of the trustees to such an extent that the trustees are their agents"). But cf. id at 521-22 (nothing that "[i]n some states [of the United States] the courts have held that the beneficiaries of a business trust are personally liable even though by the terms of the trust they have no control over the conduct of the trustees. The basis for imposing liability is that the use of the trust as a substitute for the corporate device is against public policy, as tending to evade the policy of the law against limited liability with incorporation.”); e-mail from Lionel Smith, William Dawson Scholar in Law, Faculty of Law, McGill University, to the author (May 14, 2003) (observing that, from the Canadian and English law perspective, a "crucial (and quite justified) difference between corporations and trust is that the beneficiaries/investors of a business trust are indeed very likely to bear unlimited personal liability for claims arising out of the conduct of the business, at least in the case of tort claims"). 
tity-level taxes, whereas corporations are more likely to be subject to such taxes (though separate legal existence may be important where bankruptcy remoteness is a goal). Trustees need only preserve the value of the trust's assets for claimants, which requires minimal managerial discretion and cost. In contrast, corporate managers must actively manage assets to achieve a profitable return for residual claimants.

I next apply this framework to the use of commercial trusts and corporations in securitization transactions, analyzing why and under what circumstances the trust form would be used over the corporate form.

\section{APPLICATION OF THE FRAMEWORK}

Securitization transactions exemplify the seemingly interchangeable use of trusts and corporations as forms of business organization. ${ }^{62}$ Viewing these transactions from the standpoint of the framework, however, reveals that the trust and corporate forms are not always interchangeable but tied to the transaction's underlying business purpose.

As mentioned, a primary business goal is to minimize or even avoid entity-level taxes, and this is equally true for securitization deals. ${ }^{63}$ For this reason, trusts were somewhat favored in the United States as SPVs; they could be organized to avoid these taxes, whereas (at least until recent tax law changes ${ }^{64}$ ) most corporate entities could not.

Once organized, the SPV uses the funds raised from investors to purchase financial assets from a company. The company, however, almost always retains a residual interest in those assets. ${ }^{65}$ The reten-

62. In a typical securitization transaction, a company transfers rights to payment from income-producing financial assets, such as accounts receivable, loans, or lease rentals, to an SPV, which in turn transfers such rights to a second SPV, which in turn issues securities to capital market investors. The second SPV uses the proceeds of the issuance to pay the first SPV for the financial assets, and the first SPV then uses those proceeds to pay the company. The investors, who are repaid from collections of the financial assets, buy the securities based on their assessments of the value of the financial assets. Steven L. Schwarcz, The Inherent Irrationality of Judgment Proofing, 52 STAN. L. REV. 1, 6 (1999).

63. Schwarcz, Structured Finance, A Guide to the Principles of Asset SeCURITIZATION, supra note 3, § 5:2.3, at 5-11.

64. See supra note 39.

65. See supra note 30 and accompanying text. See also Schwarcz, Alchemy, supra note 3; Schwarcz, Law and Economics of Securitization, NEw BUS. L. (JAPAN) issues 580 (Nov. 1, 1995, Part I at 35-38) and 581 (Nov. 15, 1995, Part II at 50-56). 
tion of this interest can complicate resolution of who actually owns the financial assets if the company later goes bankrupt. ${ }^{66}$ In some transactions, parties are prepared to live with this ambiguity. But where bankruptcy remoteness - in the form of a "true sale" of the financial assets from the company to the SPV-is critical to the transaction's success, ${ }^{67}$ parties often look to corporate law in order to avoid ambiguity. Corporate law usually provides a more developed legal framework than trust law because corporations have long been recognized under bankruptcy law as having separate legal existence. Securitizations thus can achieve bankruptcy remoteness by being structured as "two-tier" transactions in which the first tier is a sale of financial assets to a corporate-SPV. ${ }^{68}$

The governance criteria, however, often favor a trust over a corporate form for securitization transactions where bankruptcy remoteness is unimportant. This is because the trustee of a trust-SPV cannot (under the duty of impartiality) favor the residual claimant (settlor) over the SPV's creditors, whereas directors of a corporate SPV owe their primary fiduciary duty to residual claimants (shareholders). Creditors would be concerned, for example, that corporate directors might put the SPV into bankruptcy to protect the shareholders' equity interest therein, thereby harming creditor claims by "suspending their right to payment and possibly compromising their claims." ${ }^{69}$ Thus, in the U.S. where banks are exempt from the federal bankruptcy laws, ${ }^{70}$ securitizations involving banks often take the trust form. $^{71}$

66. Schwartz, Unraveling the Mystery, supra note 6, at 581-82.

67. Compare Schwarcz, Alchemy, supra note 3, at 135 (noting that investors may not want to take the risk of the company's bankruptcy) with Schwarcz, The Universal Language of International Securitization, supra note 7, at 291 (observing that a true sale may be unnecessary in jurisdictions where a secured creditor "would be able to enforce its rights against the [collateral] in the event of the local law equivalent of a bankruptcy case").

68. "[E]ven in a structured financing in which a ... trust is used to issue the asset-backed securities, an intermediary corporate SPV is often used as the initial transferee of assets from the originator (which SPV in turn transfers such assets to the trust) and is the bankruptcy remote SPV for which legal opinions are delivered. This is in part because of the uncertain status that a ... trust might have under applicable commercial law principles." The Committee on Bankruptcy and Corporate Reorganization of The Association of the Bar of the City of New York, Structured Financing Techniques, 50 Bus. LAw. 527, 571 n.130 (1995). See also Schwarcz, Alchemy, supra note 3, at 142 (discussion of two-tier structure).

69. Schwarcz, Rethinking A Corporation's Obligations to Creditors, supra note 22, at 684.

70. 11 U.S.C. $\S 109$.

71. Master trusts are sometimes also used, directly in transactions where bankruptcy remoteness is unimportant and indirectly (as the second SPV) in two-tier structures where bank- 


\section{FINAL OBSERVATIONS}

My examination of commercial trusts reveals a number of characteristics that might make them attractive, irrespective of the particular legal system. To the extent trusts are not viewed as separate legal entities for tax purposes, they might be used in lieu of corporations wherever an entity-level tax must be avoided and "bankruptcy remoteness" is not critical. Otherwise, the main attraction of the trust form turns on its governance characteristics.

Trusts normally operate under a duty of impartiality, which limits the ability of the trustee, as manager of the trust, to take risks in order to make the trust profitable for residual claimants at the possible expense of senior claimants. In contrast, boards of directors of corporations generally owe their primary fiduciary duty to the residual claimants (shareholders), and thus may engage in positive expected-value ventures even if there is a possibility of creditor loss. The trust form is therefore well suited (and thus arguably more efficient) for business entities whose residual claimants do not expect a high return, in contrast to the corporate form which is better suited for residual claimants that expect a high return.

For these reasons, the efficiency of forming a business entity as a trust or corporation may depend on the nature of the business's assets. If, as in an SPV used for securitization, the business has mostly financial assets whose value can be predicted with some accuracy and is unlikely to significantly increase, senior and residual claimants would focus more on protecting their interests. The trust form would facilitate this capital structure because the duty of impartiality would effectively and cheaply protect all investor interests. If, on the other hand, the business has mostly non-financial assets, the asset values may be difficult to calculate precisely. Potential senior investors then would demand a high overcollateralization in order to avoid loss, leaving a potentially significant residual value. ${ }^{72}$ Investors who want a high return and are willing to accept high risk may wish to invest in the residual claims. The corporate-form would facilitate this capital structure because the senior claimants have already protected them-

ruptcy remoteness is desirable, to diversify risk by issuing a variety of securities having different returns and risk levels, thereby maximizing funding from investors.

72. Overcollateralization means that the amount of assets dedicated to paying an investor is higher than the amount strictly necessary for such payment. Schwarcz, Alchemy, supra note 3, at 144 . 
selves by contract, whereas the residual claimants would want the directors to try to maximize the residual value. ${ }^{73}$

These observations, I realize, derive from U.S. experience with commercial trusts. They may not apply equally to foreign jurisdictions, with fundamentally different legal, economic or cultural systems. Nonetheless, it is useful to set forth the U.S. experience in order to illustrate the fundamental commercial realities underlying the use of trusts as business organizations, which in turn might serve as a starting point for foreign lawyers and comparatists interested in applying the commercial trust form to their own legal systems.

73. In this context, one might speculate what would happen if market forces caused commercial trusts to offer to sell residual interests to third parties (as I have seen in a very limited context where residual trust certificates in collateralized-debt-obligation deals are sold to thirdparty investors). Residual claimants of the trust, just like shareholders in a corporation, then may demand a rate of return that compensates them for the money they voluntarily put at risk, thereby creating a conflict with the trust's senior claimants. This, in turn, might stimulate changes in trust law, perhaps reducing the extent to which trustees are subject to liability for breach of trust by permitting them to assert a doctrine comparable to the business judgment rule as a defense, or even creating a duty of trustees to third-party residual claimants similar to the duty of corporate directors to shareholders. $C f$. Terrydale Liquidating Trust v. Barness, 611 F. Supp. 1006 (S.D.N.Y. 1984), in which the court struggled as to whether trustees of a REIT who were alleged to have breached their fiduciary duty should be judged by the corporate business judgment rule or by stricter trust law standards. The decision was that "it is appropriate to judge the conduct of REIT trustees by the standards generally applied to corporate fiduciaries." $I d$. at 1017 . The court's rationale was that "the trustees of a REIT are functionally more similar to corporate directors than to ordinary trustees," id. at 1016 (citing 16A FLETCHER CYClOPEDIA OF THE LAW OF PRIVATE CORPORATIONS \$8249, at 619 (R. Eickoff rev. ed. 1979)). 